[Agr. Biol. Chem., Vol. 27, No. 11, p. 767 772, 1963]

\title{
Genetic and Biochemical Studies on the Formation of Protease in Aspergillus sojae
}

\author{
Part II. Biochemical Studies (1)
}

\author{
By Kin-ichiro ODA \\ Noda Institute for Scientific Research, Noda City, Chiba Pref. \\ Received April 23, 1953
}

\begin{abstract}
The mutant $\mathrm{X} 816$ synthesizing protease and amylase at high rates was isolated from original strain K.S. by the irradiation of X-ray.

In order to see whether the protease in this mutant is identical with the enzyme in original strain or it is more active enzyme. Studies have been made on the protease isolated from these strains. It was found that the mutant strain synthesized the enzyme protein twice as much as original strain did. And the enzyme appears to be identical with that in original strain with respect to specific activity, electrophoresis, heat sensitivity, sedimentation constant and the elution pattern on DEAE-cellulose chromatography.
\end{abstract}

\section{INTRODUCTION}

According to a modern concept, the formation of enzyme is under the control of a specific repressor substance. In E. coli ornithine transcarbamylase ${ }^{1,2)}$ ceases to be synthesized as soon as arginine is added to the medium. These phenomena called "repression" are observed in many cases $^{3 \sim 5)}$. In case of inducible enzyme, $\beta$-galactosidase, the expression of structural gene function is also controlled by a specific repressor which is antagonized by the addition of a certain specific inducer like methyl-thio- $\beta$-D-galactoside $(\mathrm{TMG})^{6,7)}$.

However, the constitutive mutant strains $\left(i^{-}\right)$producing no repressor are able to synthesize the enzyme until it reaches a maximum level regardless of the presence of in-

\footnotetext{
1) L. Gorini and W. Gundersen, Proc. Natl. Acad. Sci. U.S., 47, 961 (1961).

2) L. Gorini, ibid., 46, 682 (1960).

3) J. Monod and G. Cohen-Bazire, Compt. rend., 236, 530 (1953).

4) B.N. Ames and B. Garry, Froc. Natl. Acad. Sci. U.S., 45, 1453 (1959).

5) H.D. Umbarger and B. Brown, J. Biol. Chem., 233, 415 (1958).

6) A.B. Pardee, F. Jacob and J. Monod, J. Mol. Biol., 1, 165 (1959).

7) F. Jacob and J. Monod, ibid., 3, 318 (1961).
}

ducer.

However, it is reported by Horiuchi et al. ${ }^{8,9)}$ that the hyper strains of $E$. coli are able to make the enzyme, $\beta$-galactosidase, up to nearly four times the normal maximum level. Such strains synthesizing enzymes at high rates are also known in the formations of ornithine transcarbamylase ${ }^{1)}$ and alkaline phosphatase $^{10,11)}$ in $E$. coli.

The strain X816 derived from original strain K.S. as a result of induced mutation is able to synthesize the enzyme, protease, twice as much as the original strain does ${ }^{12)}$. The problem what mechanisms cause the hyper synthesis of enzyme is of particular interest in relation to the control mechanisms of gene function. For this purpose, the nature of hyper synthesis of enzyme was first examined,

8) T. Horiuchi, J. Tomizawa and A. Novick, Biochim. Biophys. Acta, 55, 152 (1962).

9) A. Novick and T. Horiuchi, Cold Spr. Harv. Symp. Quant. Biol., 26, 239 (1961)

10) H. Echols, A. Garen, S. Garen and A. Toriani, J. Mol. Biol. 3, 425 (1961).

11) A. Garen and H. Echols, J. Bact., 83, 297 (1962)

12) N. Iguchi, J. Agr. Chem. Soc. Japan, 29, 73 (1955). 
by testing whether the enzyme in this mutant is identical with the enzyme of the original strain or it is an altered and more active enzyme.

\section{EXPERIMENTAL}

\section{Strains.}

The original strain, Aspergillus sojae K.S., the mutant strain X816 and the diploid strain 813 were used. The characters of these strains were described in the previous paper ${ }^{13)}$.

\section{Cultivation.}

One and a half $\mathrm{kg}$ of wheat bran was mixed with 1.51 of water and sterilized. The sterilized bran was inoculated with $40 \mathrm{~g}$ of pre-incubated cultures. The incubation was carried out at $30^{\circ} \mathrm{C}$ for $40 \mathrm{hrs}$.

\section{Purification"of Enzyme.}

The purification of enzyme followed the method originally reported by Mizunuma and $\operatorname{Iguchi}^{14)}$, and improved by Yamamoto and Hayashi ${ }^{15}$.

\section{i) Preparation Extract.}

After 40 hour incubation the bran cultures were extracted with 61 of water at $3^{\circ} \mathrm{C}$ for several hours. The eluates were first filtered with a cloth, then through a Toyo Filter Paper No. 1 (Toyo Kagaku Co.). All Subsequent operations were carried out at $3^{\circ} \sim 5^{\circ} \mathrm{C}$ unless otherwise specified.

ii) Duolite Resin Adsorption and Elution.

Duolite resin CS101 was treated with sodium hydroxide and subsequently with hydrochloric acid. After washing with water through decantation several times and finally filtration with Buchner funnel, the resin was equilibrated with $\mathrm{N} / 20$ acetate buffer $(\mathrm{pH}$ 4.8 ). One and two tenths $\mathrm{kg}$ of bufferized resin was added to about $4 \mathrm{l}$ of crude extract from the mold culture. After stirring for 10 minutes, the mixture was filtrated with a Toyo Filter Paper No. 2. The resin was washed with 51 of $\mathrm{N} / 100$ acetate buffer $(\mathrm{pH}$ 4.8 ), and then the adsorbed enzyme was eluted twice with 21 of $\mathrm{M} / 5$ phosphate buffer $(\mathrm{pH} \mathrm{7.0)}$. The eluate which showed the $\mathrm{pH} 5.2$ was adjusted to $\mathrm{pH}$ 6.0 with sodium hydroxide. The volume of eluate was about 3.0 liters.

\section{iii) Ammonium Sulfate Fractionation.}

To 31 of eluate, $1.11 \mathrm{~kg}$ of ammonium sulfate

13) K. Oda and N. Iguchi This Journal, 27, 758 (1963).

14) T. Mizunuma and N. Iguchi, ibid., 22, 35 (1958).

15) K. Yamamoto and K. Hayashi, Symp. on Enz. Chem., 18, 21 were added, and after 10 minutes the precipitate was removed by the filtration with a Toyo Filter Paper No. 2. To the filtrate an additional $666 \mathrm{~g}$ of ammonium sulfate were added with $15 \mathrm{~g}$ of Hyflosupercel, and, after one hour with occasional stirring, the precipitate was collected by filtration. This precipitate was dissolved in $300 \mathrm{ml}$ of cold water and filtrated. The filtrate was dialyzed against cold water for two days. The dialyzed enzyme solution was then lyophilized and dissolved in $30 \mathrm{ml}$ of cold water. The dialysis against cold water for overnight was carried out again.

\section{iv) DEAE-Cellulose Fractionation.}

A column $(1 \mathrm{~m} \times 1.5 \mathrm{~cm})$ was prepared from DEAEcellulose which had previously been equilibrated with $0.001 \mathrm{M}$ phosphate buffer ( $\mathrm{pH} 8.0$ ). Thirty $\mathrm{ml}$ of the dialyzed enzyme solution was passed through the column, then the column was washed with $50 \mathrm{ml}$ of the same buffer. The gradient elution was carried out by successively mixing $700 \mathrm{ml}$ of $0.001 \mathrm{~m}$ phosphate buffer $(\mathrm{pH} 8.0)$ in a mixer flask with 11 of $0.01 \mathrm{~m}$ phosphate buffer containing $0.5 \mathrm{M}$ sodium chloride in a reservoir flask, at a flow rate of about $100 \mathrm{ml}$ per hour. The eluent, $10 \mathrm{ml}$ per each tube, was collected by using a fraction collector.

\section{Starch Column Electrophoresis.}

The procedures used in this study are similar to those described in the paper by Yamamoto and Hayashi ${ }^{15)}$. Insoluble potato starch powder was washed with $0.01 \mathrm{~N}$ sodium hydroxide. The alkali was removed by washing with water, followed by with hydrochoric acid and with water. Then the starch was washed with $\mathrm{N} / 40$ barbital buffer ( $\mathrm{pH} 8.5$ ) twice, and was equilibrated with same buffer to be employed in the electrophoresis. The column used was $3 \mathrm{~cm}$ wide, $1 \mathrm{~cm}$ high and $32 \mathrm{~cm}$ long. It was developed at $5^{\circ} \mathrm{C}$ for 15 hours at $500 \mathrm{~V}$ with currents ranging from 10 $20 \mathrm{~mA}$. At the termination of the run, the starch was cut into $1.5 \mathrm{~cm}$ sections, and eluted with cold distilled water. The amount of protein and the activity of alkali protease were measured on the eluate.

\section{Sedimentation.}

The sedimentation of purified enzyme was carried out in a Spinco model $\mathrm{E}$ analytical ultracentrifuge.

\section{Enzyme Assay.}

The activity of alkali protease was assayed by the modified Anson's method ${ }^{18)}$. A unit of enzyme was

16) M.L. Anson, J. Gen. Physiol, 22, 79 (1938). 
defined as the amount causing the hydrolysis of $1 \gamma$ tyrosine in one minute.

\section{Protein Assay.}

The amount of protein was measured by the method of Lowry et al. ${ }^{17)}$, or by the ultraviolet absorption at $280 \mathrm{~m}_{\mu}$.

\section{RESULTS}

DEAE-Cellulose Chromatography.

DEAE-cellulose fractionation was carried out by above described gradient elution system. The eluent was collected in about one hundred tubes and aliquots removed from each of the tubes were used for assay of enzyme activity and estimation of protein by the ultraviolet absorption at $280 \mathrm{~m} \mu$.

In order to remove any proteinous contaminant from enzyme protein, rechromatography was carried out. The first large peak consisted largely of enzyme protein was collected (about 20 fractions), lyophilized, and then dialysed against cold water to remove sodium chloride which was used in gradient elution. The dialyzed sample was again charged on DEAE-cellulose column, and the
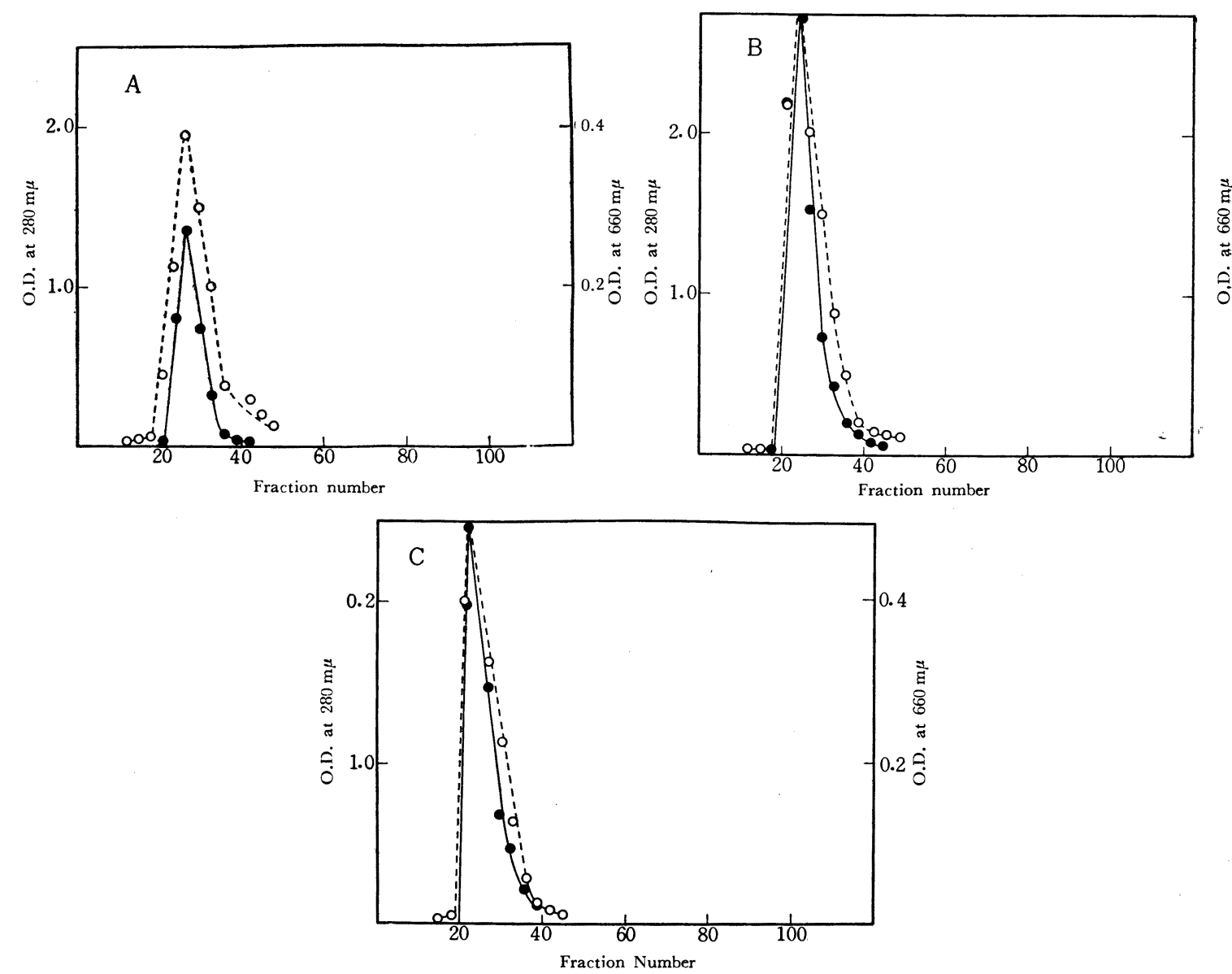

FIG. 1. Chromatographic Separation of Alkali Protease.

..- - . O.D. at $280 \mathrm{~m} \mu$ (for protein assay)

$$
\begin{array}{ll}
\text { (A) K.S. } & \text { (B) } \mathrm{X} 816
\end{array}
$$

(C) (diploid)

17) O.H. Lowry et al. J. Biol. Chem., 193, 265 (1951). 
elution was carried out at the same condition. These procedures were repeated three times for the first large peak.

In the final chromatography as shown in Fig. 1, the enzyme began to eluate at the concentration of about $0.07 \mathrm{M}$ sodium chloride in both samples of enzyme from strain K.S. and X816. The peak of enzyme activity was almost completely superimposed with that of absorption at $280 \mathrm{~m} \mu$. In this peak the enzyme protein was expected to be almost completely purified free of other protein. The fractions of this peak were collected, lyophilized, and dialyzed. This sample was used for following experiments to identify the enzyme protein in the original strain K.S. The purification of enzyme was carried out with the strains K.S., X816 and 813 simultaneously at the same scale and conditions.

Specific Activity of Enzymes Purified from Strains K.S. and X 816 .

Specific activity of enzyme was determined by the enzyme units per $1 \mathrm{mg}$ of purified enzyme protein. The results were indicated in Table I. The specific activity of purified enzyme of strain X816 was completely identical with that of original strain K.S., and as observed in Fig. 1 the amount of enzyme protein of strain X816 in the peak was about twice as much as that of strain K.S. This was quite compatible with the enzyme activity of crude extracts as shown in Table II.
TABle 1. Specific Activities of Purified ENZYMES FROM STRAINS K.S. AND X816.

$\begin{array}{lc}\text { Strain } & \begin{array}{c}\text { Enzyme units of } 1 \mathrm{mg} \\ \text { purified enzyme protein }\end{array} \\ \text { K.S. } & 370 \\ \text { X816 } & 367\end{array}$

TAble 2. Enzyme Activities of CRUde EXTRACTS* FROM STRAINS K.S., X816 AND 813.

$\begin{array}{lc}\text { Strain } & \begin{array}{c}\text { Enzyme activity } \\ \text { O.D. } 660 \mathrm{~m} \mu\end{array} \\ \text { K.S. } & 0.280 \\ \text { X816 } & 0.518 \\ 813 & 0.500\end{array}$

* The preparation of curude extracts was performed by adding 20 $\mathrm{ml}$ of water to $2 \mathrm{~g}$ of culture harvested at large scale. Above data indicate the activity of $0.5 \mathrm{ml}$ of crude extracts.

In case of diploid strain 813, which exhibited the protease activity between those of parents, although rather alike that of the strain X816, the intermediate character was reflected in both the purified enzyme fractions and crude extracts.

Sedimentation of Purified Alkali Protease from Strains K.S. and X816.

The sedimentation of purified enzyme protein of strains K.S. and X816 was carried out in a Spinco model $\mathrm{E}$ analytical ultracentrifuge at a speed of 54,000 r.p.m. The sedimentation patterns of these enzyme preparations are shown in Fig. 2. The photograph was taken every 8 minutes, about 30 minutes after reaching the speed. The sedimentation coefficients of enzymes from strains K.S. and (3) (2)

(1)

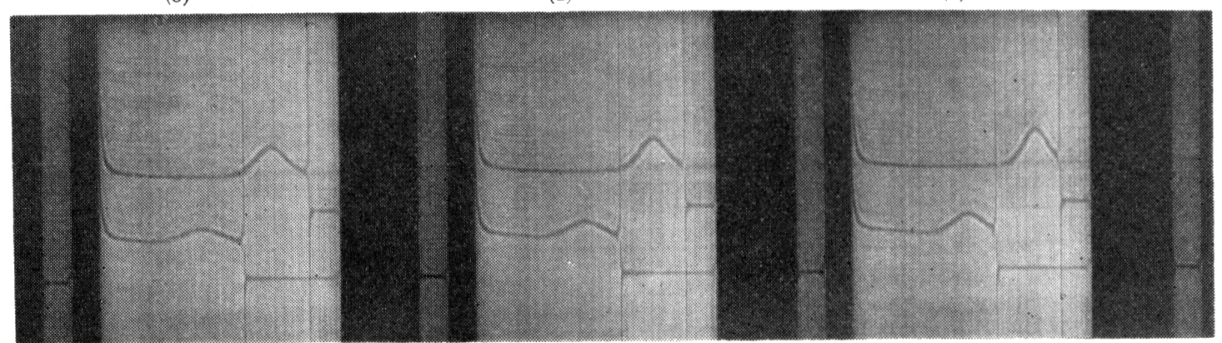

FIG. 2. Sedimentation Pattern of Purified Alkali Protease from Strains K.S. and X816.

The sample was dissolved in cold distilled water $(\mathrm{pH} 8.0)$. The photographs were taken every 8 minutes about 30 minutes after reaching full speed of 54,000 r.p.m. The pattern of sample from strains X816 and K.S. is upper and lower respectively. 
X816 calculated from these photographs were approximately $3.7 \mathrm{~S}$ and $3.0 \mathrm{~S}$ respectively. The difference of $\mathrm{S}$ values may be ascribed to the concentration effect, since the concentrations of enzyme protein in the samples of strains K.S. and X816 were about $0.25 \%$ and $0.5 \%$ respectively.

The molecular weight of enzyme was too small to be estimated by the sedimentation patterns because the sedimentation pattern was collapsed before it moved enough to take photographs from meniscus. However, it can be deduced from these sedimentation coefficients that the enzyme from strain X816 may be identical with that from original strain K.S.

\section{Starch Column Electrophoresis.}

The electrophoretic properties of purified alkali protease from strains K.S. and X816 were also examined. The mode of movement of these enzymes in the starch column electrophoresis was completely the same, as shown in Fig. 3. It is ascertained from this experiment that the enzyme from strain $\mathrm{X} 816$ is identical with that of strain K.S. electrophoretically.

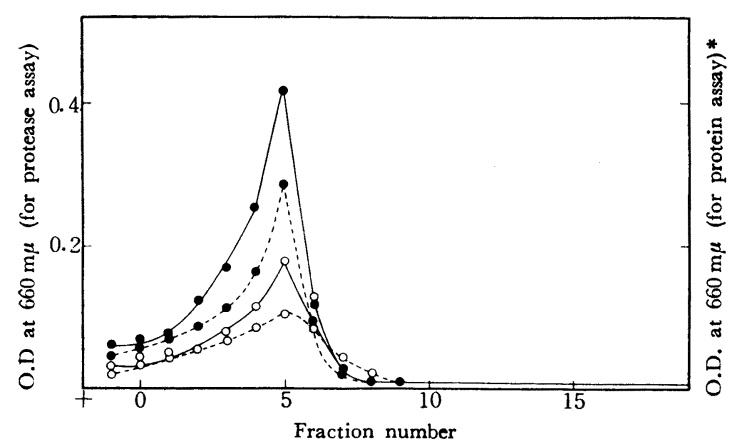

FIG. 3. Starch Column Electrophoresis of the Purified Alkali Protease Isolated from Strains K.S. and $\mathrm{X} 816$.

* The amount of protein was expressed by the O.D. at $660 \mathrm{~m} \mu$ using the method of Lowry et al.

- protease activity of purified sample from strain X816.

- - - protease activity of purified sample from strain K.S.

- .- the amount of enzyme protein from strain X816.

-...- the amount of enzyme protein from strain K.S.

\section{Heat Sensitivity of Enzymes.}

To establish further the identity of the two enzymes, thermal inactivation of purified protease was carried out. Studies were made of the rate of inactivation at $59^{\circ} \mathrm{C}$ of enzymes from strains K.S. and X816. As can be seen from the results shown in Fig. 4, samples of enzyme from the two strains are identical with respect to thermal stability.

Additional studies on the identity of two enzymes were undertaken by assaying the relative affinity of the enzyme to the substrates, benzoyl-L-arginine amide, and carbobenzoxy-L-glutamyl-L-tyrosine. However, the peptidase activity of the sample on these substrates was too weak to determine the Michaelis constant.

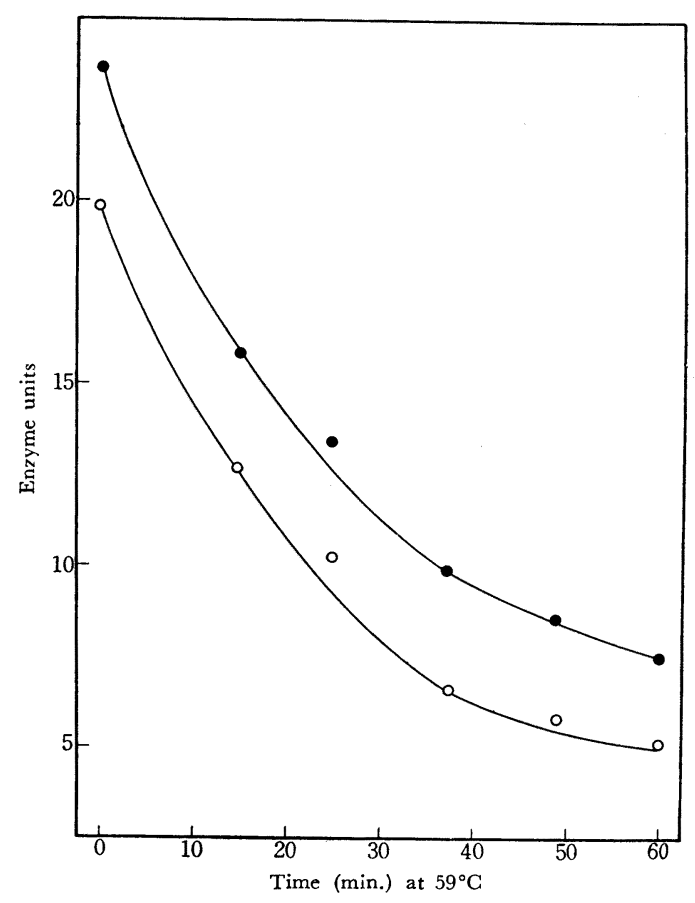

FIG. 4. Thermal Inactivation of Purified Alkali Protease from Strains K.S. and X816. at $59^{\circ} \mathrm{C}$. ( $\mathrm{pH} 7.0)$.

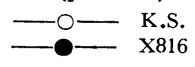




\section{DISCUSSION AND CONCLUSIONS}

It can be concluded from the above described experiments that the enzyme, protease, of mutant strain is identical with that of original strain K.S., and that the strain $\mathrm{X} 816$ is able to synthesize this enzyme protein twice as much as the original strain does. This situation may also be available for the formation of amylase in the mutant strain $\mathrm{X} 816$.

In case of the enzyme, $\beta$-galactosidase, in $E$. coli, it is reported by Horiuchi and Novick ${ }^{18)}$ that the hyper strain can produce $\beta$-galactosidase up to four times as compared with the wild type strains. The ability for the hypersynthesis of enzyme was ascribed to the extra segments carrying the Lac region associated with the bacterial chromosome.

However, in our strain X816 which was induced from original strain K.S. by X-ray irradiation, the occurrence of extra segments was unlikely. The ability of synthesizing protease at high rates could be the result of a point mutation provoking the effective function of a protease gene.
Judging from the coordinate hyper productions of both protease and amylase, it is assumed that the mutation has occurred in the locus similar to an "operater gene" that has been proposed by Jacob and Monod") in the model of genetic regulation for protein synthesis. However, further genetic studies supporting this hypothesis was quite difficult in the present system. As a biochemical approach to this problem, studies on whether or not the hyper-production of these enzymes is the result of hyper-synthesis of messenger RNA responsible for these enzyme syntheses are now under progress.

Acknowledgement. The author would like to express his sincerest thanks to Prof. Y. Ikeda and Dr. H. Saito, University of Tokyo, for their valuable suggestions and discussions. The author also express his thanks to Dr. J. Ono, the National Institute for Radiological Science, for his kind help and advices in the ultracentrifugical analysis, and to $\mathrm{Mr}$. $\mathrm{K}$. Hayashi in carrying out these experiments. Thanks are also due to Director M. Mogi for his kind encouragements.

18) Horiuchi and Novick, Genetics, in press. 